\section{Pacific Northwest}

National Laboratory

Operated by Battelle for the

U.S. Department of Energy

\title{
Scoping Study for the Demand Response DFT II Project in Morgantown, WV
}

S. Lu

M. Kintner-Meyer

March 2008

Prepared for

U.S. Department of Energy

under Contract DE-AC05-76RL01830 


\title{
DISCLAIMER
}

This report was prepared as an account of work sponsored by an agency of the United States Government. Neither the United States Government nor any agency thereof, nor Battelle Memorial Institute, nor any of their employees, makes any warranty, express or implied, or assumes any legal liability or responsibility for the accuracy, completeness, or usefulness of any information, apparatus, product, or process disclosed, or represents that its use would not infringe privately owned rights. Reference herein to any specific commercial product, process, or service by trade name, trademark, manufacturer, or otherwise does not necessarily constitute or imply its endorsement, recommendation, or favoring by the United States Government or any agency thereof, or Battelle Memorial Institute. The views and opinions of authors expressed herein do not necessarily state or reflect those of the United States Government or any agency thereof.

\author{
PACIFIC NORTHWEST NATIONAL LABORATORY \\ operated by \\ BATTELLE \\ for the \\ UNITED STATES DEPARTMENT OF ENERGY \\ under Contract DE-AC05-76RL01830
}

\author{
Printed in the United States of America \\ Available to DOE and DOE contractors from the \\ Office of Scientific and Technical Information, \\ P.O. Box 62, Oak Ridge, TN 37831-0062; \\ ph: (865) 576-8401 \\ fax: (865) 576-5728 \\ email: reports@adonis.osti.gov
}

\footnotetext{
Available to the public from the National Technical Information Service, U.S. Department of Commerce, 5285 Port Royal Rd., Springfield, VA 22161 ph: (800) 553-6847 fax: (703) 605-6900

email: orders@ntis.fedworld.gov

online ordering: http://www.ntis.gov/ordering.htm

This document was printed on recycled paper.
} 


\section{Scoping Study for Demand Response DFT II Project in Morgantown, WV}

S. $\mathrm{Lu}$

M. Kintner-Meyer

March 2008

Prepared for

the U.S. Department of Energy

under Contract DE-AC05-76RL01830

Pacific Northwest National Laboratory

Richland, Washington 99352 


\section{SUMMARY}

This scoping study describes the underlying data resources and an analysis tool for a demand response assessment specifically tailored toward the needs of the Modern Grid Initiatives Demonstration Field Test in Phase II in Morgantown, WV. In order to develop demand response strategies as part of more general distribution automation, automated islanding and feeder reconfiguration schemes, an assessment of the demand response resource potential is required. This report will provide and present the data for the resource assessment for residential customers and describes a tool that allows the analyst to estimate demand response in $\mathrm{kW}$ for each hour of the day, by end-use, season, day type (weekday versus weekend) with specific saturation rates of residential appliances valid for the Morgantown, WV area. 


\section{CONTENTS}

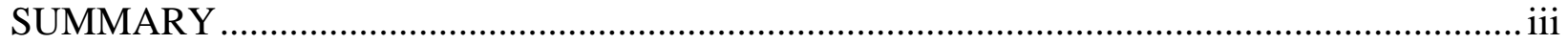

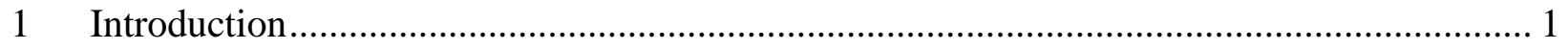

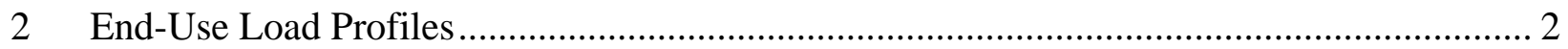

2.1 Identify candidate DR loads............................................................................. 2

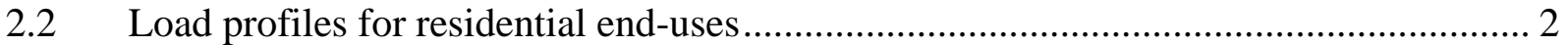

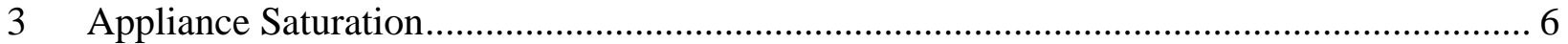

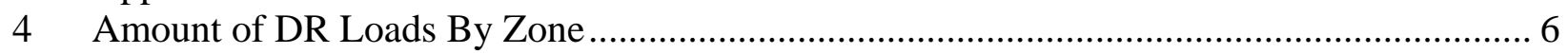

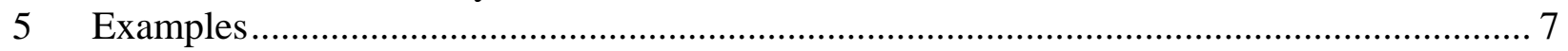

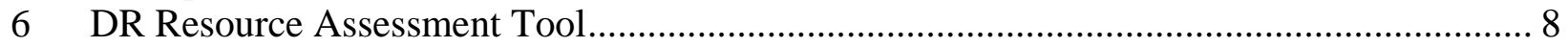




\section{FIGURES}

Figure 1: DOE-2.2 Simulation Results for Air-Conditioning and Electric Space Heating Load in

Morgantown ................................................................................................................... 3

Figure 2: Summer Weekday Average Residential Loads ................................................................ 4

Figure 3: Summer Weekend Average Residential Load.................................................................... 4

Figure 4: Winter Weekday Average Residential Loads ............................................................. 5

Figure 5: Winter Weekend Average Residential Loads ………..................................................... 5

Figure 6: Zone Definition of Morgantown Power System .......................................................... 6 


\section{TABLES}

Table 1: Saturation rates by appliance type in Morgantown .............................................. 6

Table 2: Number of residential homes in each zone of Morgantown system.............................. 7

Table 3: Summer weekday residential loads at 3 pm .......................................................... 7

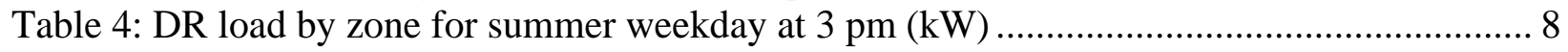




\section{Introduction}

This scoping study provides an estimate of the load resource potential for appliance-based demand response (DR) strategies. This DR resource assessment supports the Morgantown Demonstration Field Test, Phase II, of the Modern Grid Initiative (MGI). The study focuses on end-uses and appliances for residential customers in very specific and targeted feeders in Morgantown, WV. The purpose of this load resource assessment is to provide a load relief assessment critical for the MGI contractors to develop optimal islanding and distribution automation strategies that will demonstrate new and advanced technologies for improving reliability in distribution systems.

The selected feeder in Morgantown is part of the $12.5 \mathrm{kV}$ distribution system. The demand response resource potential is presented in this report by zones (as defined by the MGI contractors), end-use, time of day, season, and for weekdays and weekends. Pacific Northwest National Laboratory (PNNL) developed a tool to estimate the load-relief potential for single or multiple end-uses, for one or several zones, for a given hour of the day. The tool is based on existing end-use load data and then scaled to defined populations of residential customers that are located on the designated feeder in Morgantown. As such, it does not consider dynamic load response, such as the rebound effect after a dispatch of air-conditioning units when the load is reconnected. However, this simplified load resource estimation approach provides a reasonable and plausible quantification of the load resources that can be called upon and utilized during brief durations (less than 1 hour). It may, however, overestimate the resource potential for DR calls that span over several hours. Under these conditions, the residential customer is likely to resume the interrupted process in an appliance even during the DR event.

This report provides a brief overview of the end-use load data used for this assessment. It then describes the appliance saturation for residential customers and the distribution of residential customers in specific zones defined for islanding strategies in the designated demonstration feeders. The total load resource potential by end-use, by zone, and by hour of a weekday is provided. Finally, the load resource assessment tool is briefly described to enable MGI contractors to use it for answering specific load resource questions. 


\section{End-Use Load Profiles}

\subsection{Identify candidate DR loads}

Not all types of residential end-use loads are appropriate candidates for demand response strategies. Candidates are those end-uses that have minimal or even no noticeable impacts to the consumer. Those are end-uses that generally use thermostatically controlled loads with sufficient thermal storage to maintain their service during brief power interruptions. Examples are electric hot water heaters, space heaters, and refrigerators. Home electronics, such as TVs, radios, computers, as well as lighting, do not lend themselves to demand response strategies because any electricity interruption disrupts the desirable service of the appliance or device. The following residential end-uses are recommended for demand response strategies consideration over short duration:

(1) Standalone freezer

(2) Refrigerator

(3) Clothes washer

(4) Clothes dryer

(5) Electric water heater

(6) Air-conditioning

(7) Electric space heating.

The above loads contribute to more than $90 \%$ of residential power consumptions.

\subsection{Load profiles for residential end-uses}

The load profiles for the end-use candidates above are based on ELCAP (End-Use Load and Consumer Assessment Program) data set ${ }^{1}$. The profiles show the average power consumption of appliances existing in a large number of residential houses during each hour, for 24 hours. These end-use consumption monitoring was performed in the Pacific Northwest and, thus, is strictly valid only for this region. However, consumption patterns for weather-independent loads that are determined by common customer schedules tend to be similar throughout the U.S. To generate load profiles for weather-dependent loads, such as space heating and cooling, building simulations were performed using the Department of Energy's building simulation program DOE- $2.2^{2}$ for a typical summer and winter day in Morgantown, WV.

To take into consideration the change of load profiles caused by season and work activities, the load profiles are separated into the two seasons and two typical days of the week as follows:

(1) Summer weekday

(2) Summer weekend

(3) Winter weekday

(4) Winter weekend.

\footnotetext{
1 J. Cahill, K. Ritland, W. Kelly, Description of Electric Energy Use in Single Family Residences in the Pacific Northwest 1986-1992, End Use Load and Consumer Assessment Program (ELCAP), Office of Energy Resources, Bonneville Power Administration, Portland, OR, December 1992.

${ }^{2}$ DOE-2 is a widely used and accepted freeware building energy analysis program DOE-2.2 is the newest DOE-2 simulation and cost calculation engine. Program download is available online: http://www.doe2.com.
} 
The definition of "summer" is from June 1 to August 31, and "winter" is defined as December 1 through the end of February. The definition of "weekday" is Monday to Friday, and "weekend" is Saturday and Sunday.

Figure 1 shows the air-conditioning and electric space heating load obtained from DOE-2.2 simulations. The majority of electric space heating load in residential homes is forced-air heating system with electric resistance or heat pump. According to Residential Energy Consumption Survey (RECS) ${ }^{3}$ database, Morgantown is in the South Atlantic Census division. Among the residential electric heating systems in this area, RECS indicates that $40 \%$ are electric resistance (either baseboard or furnace) and 60\% are heat pump. The curve for heating load in Figure 1 is the average of these two systems weighted by their ratio $40 \%$ and $60 \%$, respectively. The simulations did not explore the diversity associated with different heating and cooling schedules and their effect on the load profiles, rather it used the default schedule in DOE2 software. As the consequence, only one uniform schedule was used for both weekdays and weekends. The result are representative of a typical and deterministic schedule.

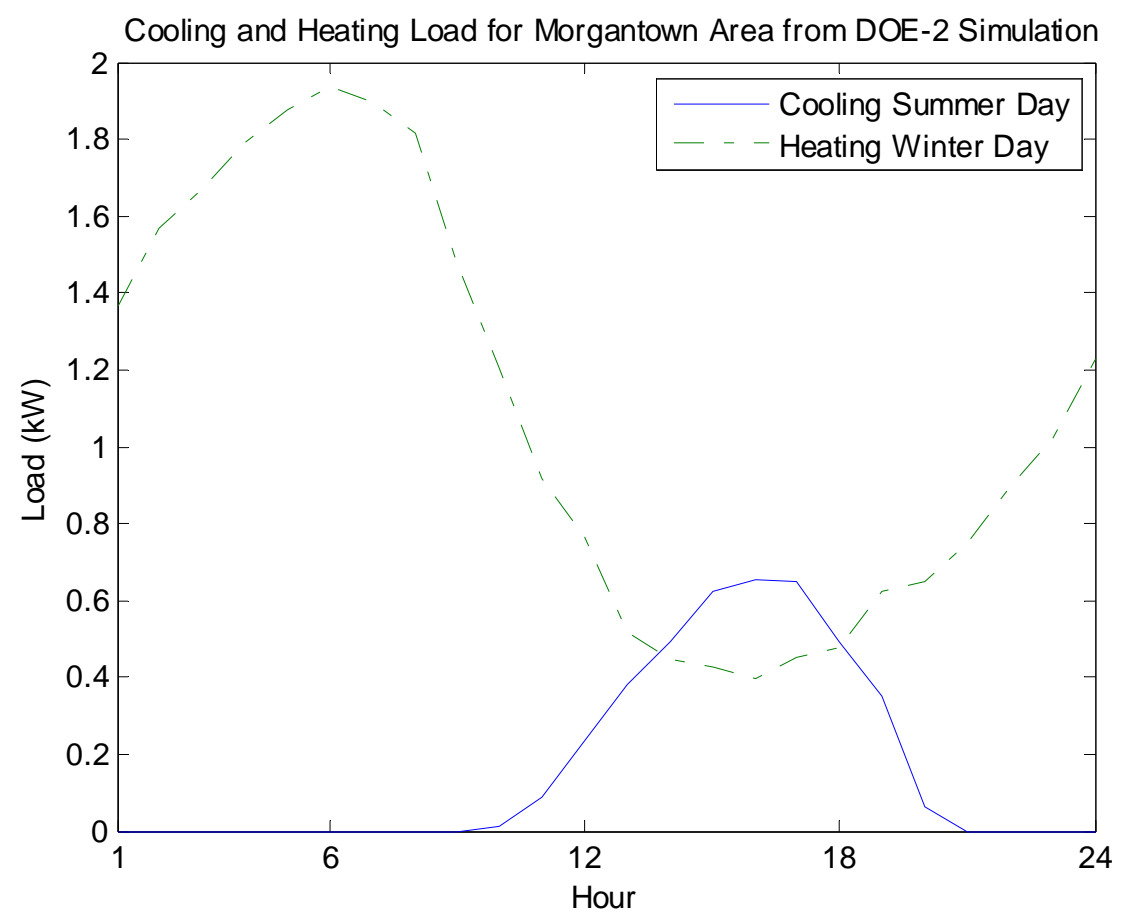

Figure 1: DOE-2.2 Simulation Results for Air-Conditioning and Electric Space Heating Load in Morgantown

Figures 2 through 5 show hourly profiles of the aggregated DR potential of candidate end-uses in the four different day types. The data on weather-independent loads are from ELCAP data, and the weather-dependent loads are obtained from DOE-2.2 simulation, as shown in Figure 1. The load $\mathrm{kW}$ value at each hour represents the average power demand of a set of appliances during that hour. The averages are determined from homes with $100 \%$ saturation of each end-use

\footnotetext{
${ }^{3}$ The Residential Energy Consumption Survey (RECS) is a national sample survey of housing units, conducted by the Energy Information Administration of the U.S. Department of Energy. Data files are available online: http://www.eia.doe.gov/emeu/recs/recs2001/publicuse2001.html.
} 
appliance. This means homes without a specific appliance are excluded from the averaging calculations.

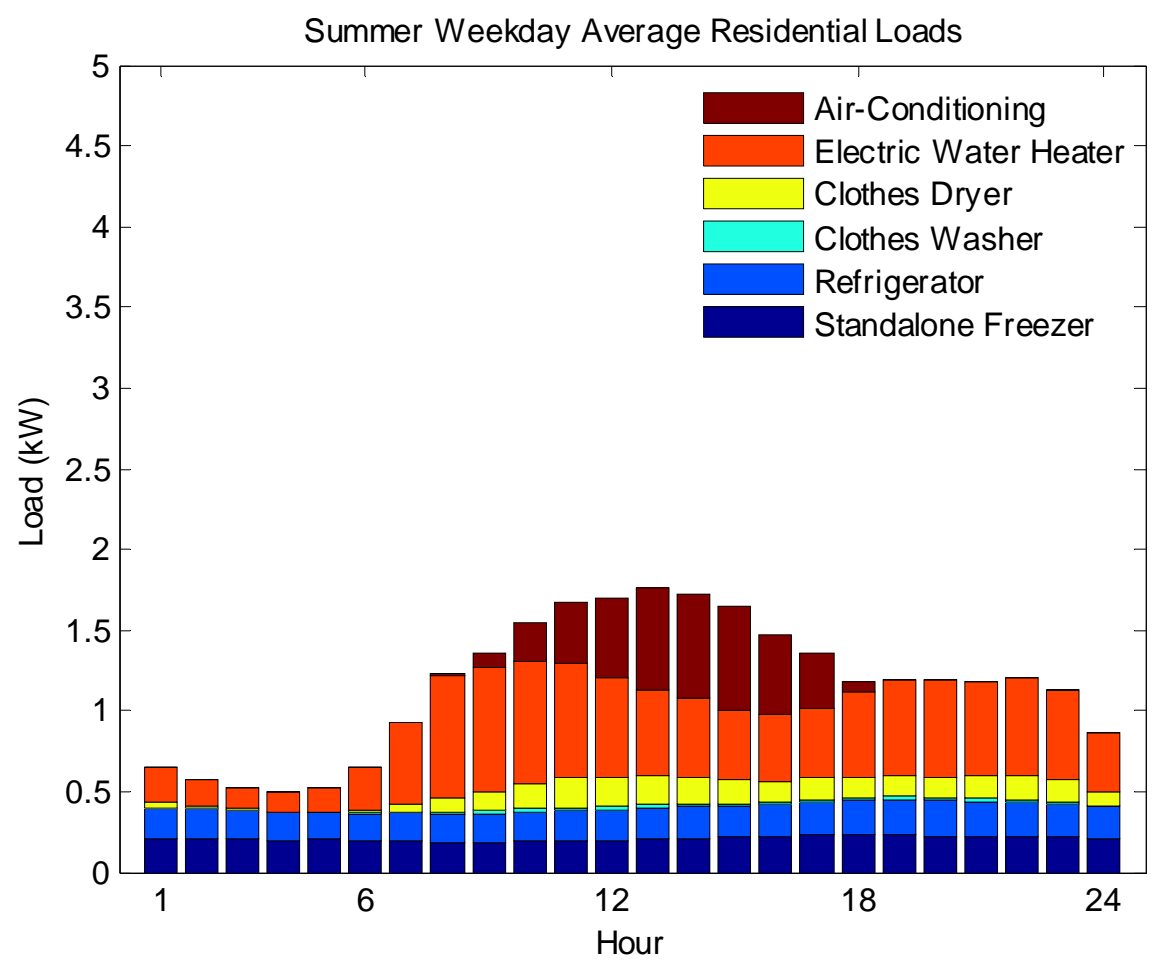

Figure 2: Summer Weekday Average Residential Loads

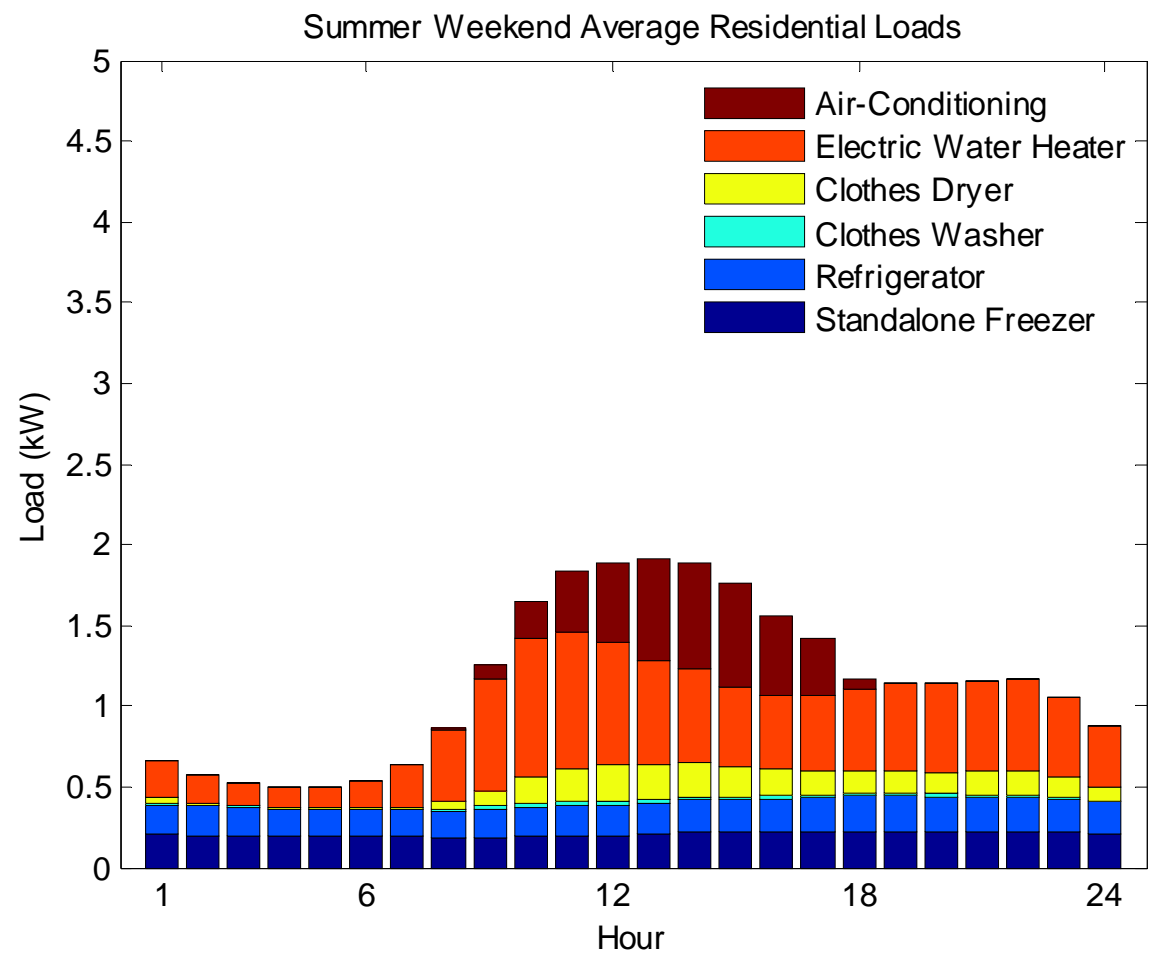

Figure 3: Summer Weekend Average Residential Load 


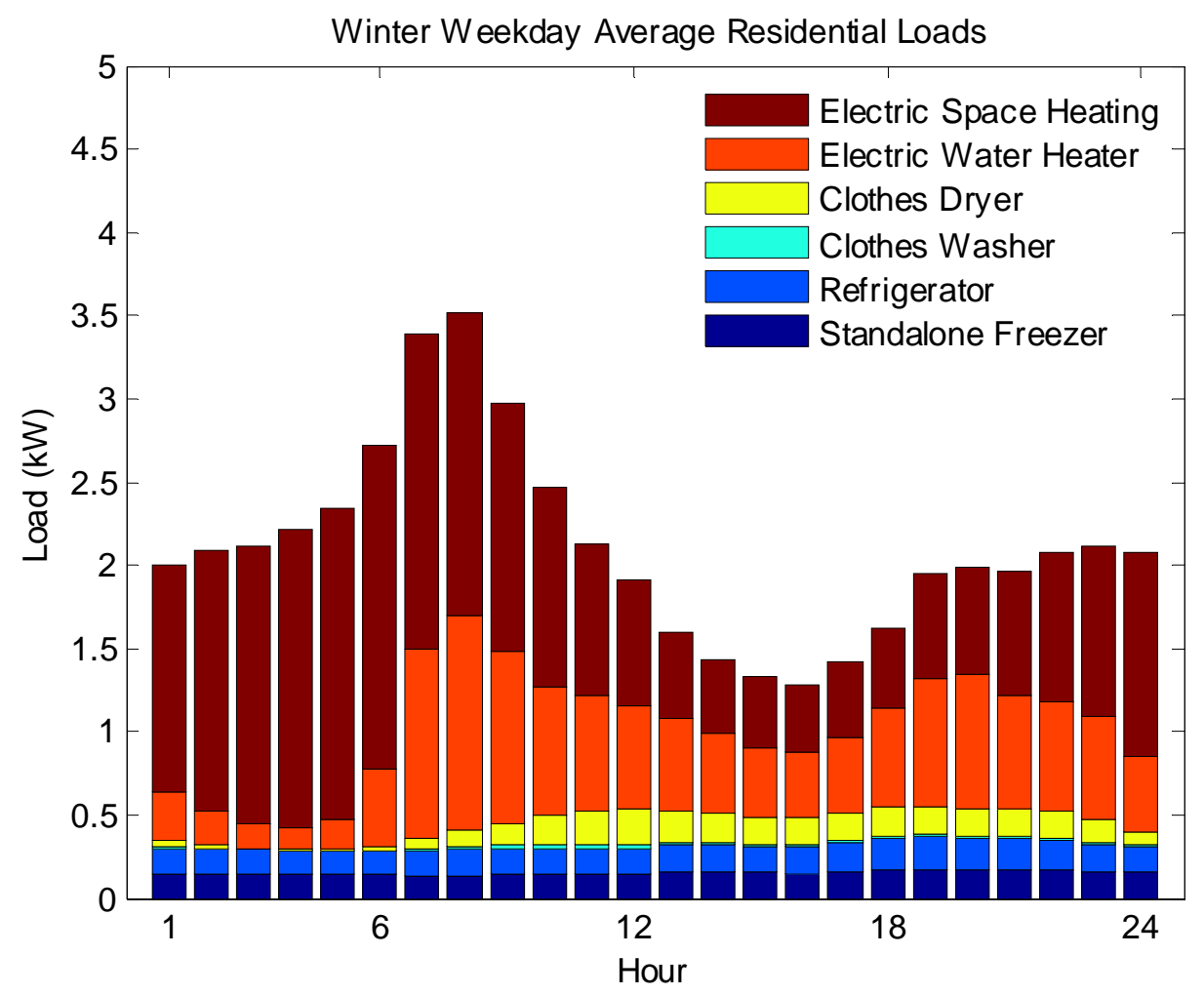

Figure 4: Winter Weekday Average Residential Loads

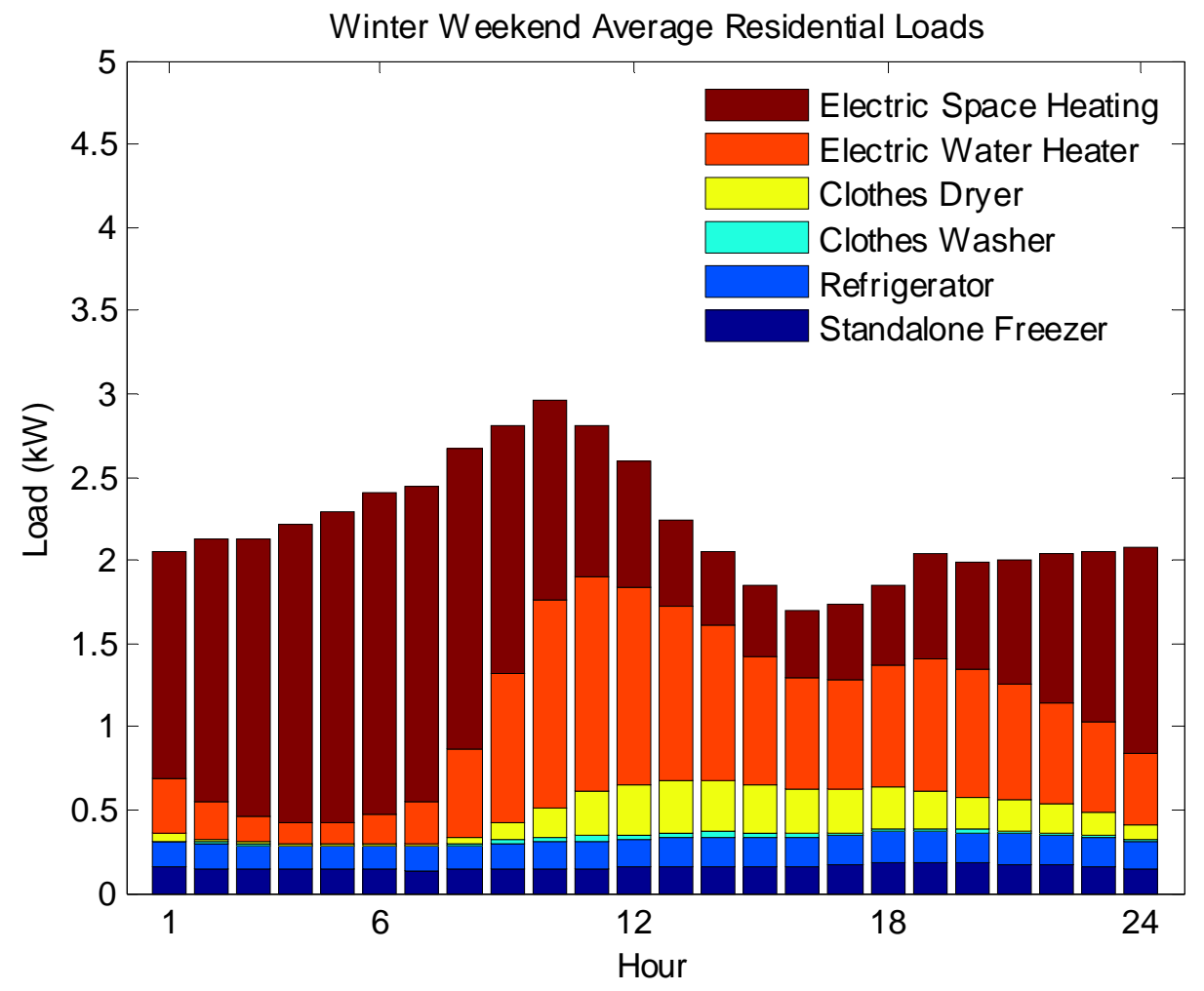

Figure 5: Winter Weekend Average Residential Loads 


\section{Appliance Saturation}

To assess the DR resource potential for each residential candidate end-use, appliance saturation data are required. The saturation rate of an appliance is defined as the number of homes that own the specific appliance vs. the total number of homes in the area under study. The MGI contractors provided the data applicable for Morgantown. The data originated from Allegheny Power and are shown in Table 1.

Table 1: Saturation rates by appliance type in Morgantown

\begin{tabular}{|c|c|c|c|c|c|c|c|}
\hline & $\begin{array}{c}\text { Standalone } \\
\text { Freezer }\end{array}$ & Refrigerator & $\begin{array}{c}\text { Clothes } \\
\text { Washer }\end{array}$ & $\begin{array}{c}\text { Clothes } \\
\text { Dryer }\end{array}$ & $\begin{array}{c}\text { Electric } \\
\text { Water Heater }\end{array}$ & $\begin{array}{c}\text { Air- } \\
\text { Conditioning }\end{array}$ & $\begin{array}{c}\text { Electric } \\
\text { Space } \\
\text { Heating }\end{array}$ \\
\hline $\begin{array}{c}\text { Saturation } \\
\text { Rate (\%) }\end{array}$ & 54 & 100 & 93 & 74 & 46 & 48 & 22 \\
\hline
\end{tabular}

\section{Amount of DR Loads By Zone}

The Morgantown demonstration feeders are divided into eight distinct zones for testing of fault detection, automatic islanding and system reconfiguration strategies (see Figure 6). To estimate the load resource potential by zone, the number of residential homes in each zone is needed. This data were obtained from the MGI contractors for the Morgantown system. The number of homes in each zone is listed in Table 2.

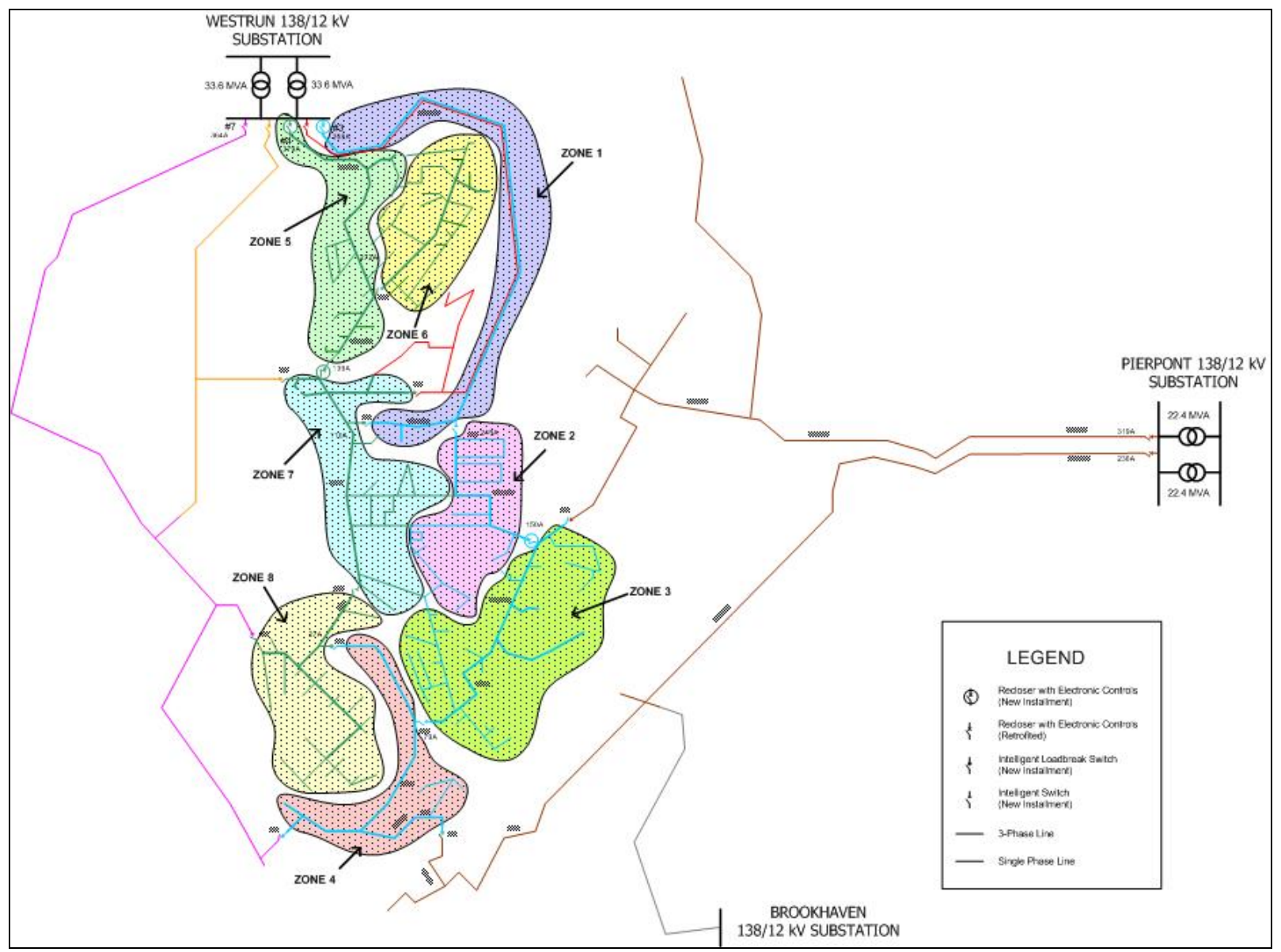

Figure 6: Zone Definition of Morgantown Power System 
Table 2: Number of residential homes in each zone of Morgantown system

\begin{tabular}{|c|c|c|c|c|c|c|c|c|}
\hline Zone & 1 & 2 & 3 & 4 & 5 & 6 & 7 & 8 \\
\hline \# of homes & 385 & 748 & 626 & 409 & 257 & 727 & 460 & 1127 \\
\hline
\end{tabular}

With the end-use load data, the saturation rates, number of homes per zone, the DR resource potential can be estimated as follows:

DR resource potential $(\mathrm{i}, \mathrm{j}, \mathrm{k}, \mathrm{l}, \mathrm{z})=$

$$
\text { Load profile }(\mathrm{i}, \mathrm{j}, \mathrm{k}, \mathrm{l}) * \text { Number of homes in zone }(\mathrm{z}) * \text { Saturation rate }
$$

where

$\begin{array}{ll}\mathrm{i} & \text { hour of day }(1 \ldots 24) \\ \mathrm{j} & \text { season (summer, winter) } \\ \mathrm{k} & \text { day type (weekday, weekend) } \\ \mathrm{l} & \text { end-use type } \\ \mathrm{z} & \text { zone number }(1 \ldots 8)\end{array}$

\section{Examples}

A tool was developed to estimate the DR resource potential according to Equation (1). An example illustrates how this tool could be used.

Assume that the DR resource potential is sought for a time slice around $3 \mathrm{pm}$ in June, on a weekday. Table 3 shows the result for a single residential customer at $3 \mathrm{pm}$ in the summer. These values represent average $\mathrm{kW}$ demands over a period of 1 hour at the given time of the day. These demands are representative of an average customer utilizing the native load diversity of a population of residential customers (from the attribute of ELCAP data), plus the diversity of loads from different saturation rates for the West Virginia population by zone.

Table 3: Summer weekday residential loads at 3 pm

\begin{tabular}{|c|c|c|c|c|c|c|c|}
\hline End-Use & $\begin{array}{c}\text { Stand Alone } \\
\text { Freezer }\end{array}$ & Refrigerator & $\begin{array}{c}\text { Clothes } \\
\text { Washer }\end{array}$ & $\begin{array}{c}\text { Clothes } \\
\text { Dryer }\end{array}$ & $\begin{array}{c}\text { Electric } \\
\text { Water Heater }\end{array}$ & $\begin{array}{c}\text { Air } \\
\text { Conditioning }\end{array}$ & $\begin{array}{c}\text { Electric } \\
\text { Space } \\
\text { Heating }\end{array}$ \\
\hline Power(kW) & 0.219 & 0.194 & 0.0145 & 0.145 & 0.43 & 0.649 & 0 \\
\hline
\end{tabular}

Using Equation (1) in section 4, we can estimate the DR loads in each zone, as shown in Table 4. 
Table 4: DR load by zone for summer weekday at 3 pm (kW)

\begin{tabular}{|c|c|c|c|c|c|c|c|c|c|}
\hline Zone & $\mathbf{1}$ & $\mathbf{2}$ & $\mathbf{3}$ & $\mathbf{4}$ & $\mathbf{5}$ & $\mathbf{6}$ & $\mathbf{7}$ & $\mathbf{8}$ & Total \\
\hline Stand Alone Freezer & 46 & 88 & 74 & 48 & 30 & 86 & 54 & 133 & $\mathbf{5 6 0}$ \\
\hline Refrigerator & 75 & 145 & 121 & 79 & 50 & 141 & 89 & 219 & $\mathbf{9 1 9}$ \\
\hline Clothes Washer & 5 & 10 & 8 & 6 & 3 & 10 & 6 & 15 & $\mathbf{6 4}$ \\
\hline Clothes Dryer & 41 & 80 & 67 & 44 & 28 & 78 & 49 & 121 & $\mathbf{5 0 9}$ \\
\hline Electric Water Heater & 76 & 148 & 124 & 81 & 51 & 144 & 91 & 223 & $\mathbf{9 3 7}$ \\
\hline Air Conditioning & 120 & 233 & 195 & 128 & 80 & 227 & 143 & 351 & $\mathbf{1 4 7 7}$ \\
\hline Electric Space Heating & 0 & 0 & 0 & 0 & 0 & 0 & 0 & 0 & $\mathbf{0}$ \\
\hline Total DR load & $\mathbf{3 6 3}$ & $\mathbf{7 0 5}$ & $\mathbf{5 9 0}$ & $\mathbf{3 8 6}$ & $\mathbf{2 4 2}$ & $\mathbf{6 8 5}$ & $\mathbf{4 3 4}$ & $\mathbf{1 0 6 2}$ & $\mathbf{4 4 6 7}$ \\
\hline
\end{tabular}

The total amount of DR loads is the number on the lower right corner of the table, which is 4467 $\mathrm{kW}$.

\section{DR Resource Assessment Tool}

A tool ${ }^{4}$ was developed at PNNL to estimate the load-relief potential for single or multiple enduses, for one or several zones, for a given hour of the day. The tool was developed in MATLAB ${ }^{5}$. It requires the MATLAB file "DRLoadEstimator.m" and a Microsoft Excel file "Load Estimator Data Source.xls". The Excel file includes load profiles. The Matlab file evaluates Equation (1). The tool is designed to prompt the user in an interactive mode by requesting the following input information: day type, hour, load type, zone, etc. Then the tool outputs the amount of load corresponding to the situation the user has chosen. Input data used by the tool are stored in the Excel file "Load Estimator Data Source.xls". The spread sheet includes all load profiles, appliance penetration rates, and total numbers of homes by zone, which are explained in section 2, 3 and 4, respectively. Users can change the content of the data file, such as number of homes in each zone and appliance penetration rate, according to his/her particular situation.

\footnotetext{
4 The assessment tool and related data files can be obtained by contacting the authors: Shuai.lu@pnl.gov and Michael.Kintner-Meyer@pnl.gov.

${ }^{5}$ MATLAB is a product of The MathWorks, Inc.
} 